\title{
MEU CARO PROFESSOR
}

\author{
Ana Maria Loffredo \\ Instituto de Psicologia - USP
}

\begin{abstract}
professor costumava levar os livros e cadernos bem rente ao peito, num gesto de caminhar quase apressado de que me lembro tão bem. Parecia formal, com aquela expressão séria, quase grave. Mas esse era só o começo. Aos poucos, era possível captar uma ternura quase tímida que vinha por detrás dos óculos e nos atravessava com um olhar agudo de interesse e respeito. Nesse elo de súbita confiança, iniciava-se aquele processo cheio de sutilezas, de ritmos delicados, de turbulê ncias inquietantes, que é a transmissão de conhecimento em psicanálise.
\end{abstract}

Não se levam mais maçãs para o professor como antigamente e, no cotidiano da universidade, tudo se passa como se as flores de gratidão tivessem ficado meio fora de moda. É que a gratidão se apresenta em singularidades avessas a estereótipos, pois a melhor homenagem se faz visível nas marcas de seu ensino, que lançam o aprendiz na árdua aventura da conquista de seu próprio estilo, expresso em frutos tão peculiares, que sua filiação fica quase irreconhecível.

Nos bastidores pulsantes e nos bancos de concreto do Instituto de Psicologia, em meio àquele tumulto de vozes, sanduíches, encontros entrecortados, xales e pulseiras, bancas de livros e namoros, o aluno pode vislumbrar a chance da subversão de si, nas maçãs generosas oferecidas pelo mestre verdadeiro. Ele nos incita ao exercício da autonomia, ao se dispor ao contato com a diversidade, sem fazer uso de concessões e inspirando-se nas idéias que lhe são mais caras.

A porta da sala se abre e o tom das vozes se abaixa, em sintonia com os passos do professor. Ele apóia os livros sobre a mesa, espalha brevemente o olhar pelos alunos, há até um certo suspense, pois o professor não é dado a 
muitas mesuras e a sorrisos fáceis. Está instaurada a cena didática. E nós sabemos muito bem, quando, neste cenário, alguém faz a diferença: "Gente, as aulas do Luiz Carlos estão cada vez melhores".

Também era possível que chegasse a uma banca de qualificação, quase surpreso pelo convite para estar ali e, com gentileza, perguntasse : bem, eu não penso dessa forma, você sabe, como posso contribuir? Então, começava a falar num ritmo tal que as idéias pareciam fios que iam se desenrolando devagar, como se produzidos por uma tecelagem já serena de seu tempo de maturidade, fiel a seus princípios, porém generosa na fertilidade das impressões precisas e dos desdobramentos que brotavam sem esforço, como num texto pronto. Quando ele parava de falar e parecia que tinha terminado, não, era só uma pausa, como se pensasse alto e novos argumentos aparecessem, enquanto seus dedos finos de pianista burilavam as bordas dos textos, livros, teses, como se acompanhassem o inquietante ritmo das idéias e, ao mesmo tempo, exercitassem a paciência com as temporalidades inevitáveis.

Talvez a paixão do professor pela psicanálise e do psicanalista pela transmissão conseguissem provocar aquela atmosfera por vezes desconcertante e desestabilizante, tão pertinente ao contato com o discurso psicanalítico, como se súbitas experiências de Unheimliche nos anunciassem que processos criativos estavam em curso e que a ética da psicanálise estava em operação.

É que saber sem sabor não há, e é do casamento da paixão e da razão que pode surgir o ato amoroso da produção de conhecimento. E o que pensar do amor? "Não penso nada", responde Barthes, "bem que eu gostaria de saber o que é, mas estando do lado de dentro, eu o vejo em existência, não em essência. Estou no mau lugar do amor, que é seu lugar iluminado. ' $O$ lugar mais sombrio', diz um provérbio chinês, 'é sempre embaixo da lâmpada"”.

Obrigada, professor, pelo estímulo ao prazer do texto, que se alimenta de lâmpadas e fustiga obscuridades insuspeitas. 